\title{
GAMETIC GENE TRANSFER IN INDIAN MUSTARD (BRASSICA JUNCEA (L.) COSS.)
}

\author{
SURINDER S. BANGA, SHASHI K. BANGA AND K. S. LABANA \\ Department of Plant Breeding, Punjab Agricultural University, Ludhiana (India) \\ Received 1.ii.84
}

\section{SUMMARY}

\begin{abstract}
The concept of gene transfer using irradiated pollen was investigated in Brassica juncea (L.) Coss. The $\mathrm{M}_{1}$ and $\mathrm{M}_{2}$ generations derived from the pollinations with heavily irradiated pollen $(25,35$ and $50 \mathrm{Krad})$ showed a greater similarity with the maternal parent for both qualitative and quantitative traits. In general, the similarity increased with an increase in radiation dose. The results indicate the random transfer of paternal characters, and their expression in maternal background.
\end{abstract}

\section{INTRODUCTION}

The matromorphic development of embryos after prickle pollination has been demonstrated in Brassica juncea (Banga and Labana, 1983). A modification of this technique involves the use of highly irradiated pollen not for producing true matromorphs but for the limited transfer of characters from one genotype to another. Evidence has been presented for the success of irradiated pollen technique in effecting the selective transfer of both qualitative and quantitative traits in Nicotiana (Virk et al., 1977; Pandey, 1978; Caligari et al., 1981) and barley (Powell et al., 1983). The experiments described in this paper report such an attempt in Indian mustard.

\section{Materials And Methods}

Two different strains of $B$. juncea $(2 n=36)$ with homozygous recessive genotypes, one for no false septum (NFS-1) and another for white flower (WF-1) were used as maternal parents. CV. RLM 198 with homozygous dominant genotypes for both these markers was used as the pollen parent. The pollen from RLM 198 was irradiated with $0,25,35$ and $50 \mathrm{Krad}$ of gamma rays and used to pollinate flowers of NFS-1 and WF-1. Controlled emasculations without pollination were used to detect spontaneous parthenogenesis. The pollen tube penetration in each cross was recorded in fifty random flowers after 96 hours of pollination. Individual harvesting of siliquae was done at maturity.

All the matromorphic $M_{1}$ plants $(2 n=36)$ having the expression of any paternal marker were selfed to produce the $M_{2}$ generation. In addition, a sample of 10 plants in remaining matromorphic $\mathbf{M}_{1}$ populations was also selfed to produce the $\mathbf{M}_{2}$. Three hundred individuals each of selected and unselected $\mathrm{M}_{2}$ populations along with 20 plants each of the parents and $F_{1}$, and $100 F_{2}$ plants were raised in a single plant randomisation with two replications during winter, 1981 . Seeds were space planted with a distance of $15 \mathrm{~cm}$ plant to plant and $45 \mathrm{~cm}$ row to row. Two seeds per hill were sown. Thinning was carried out 20 days after germination. The scoring for 


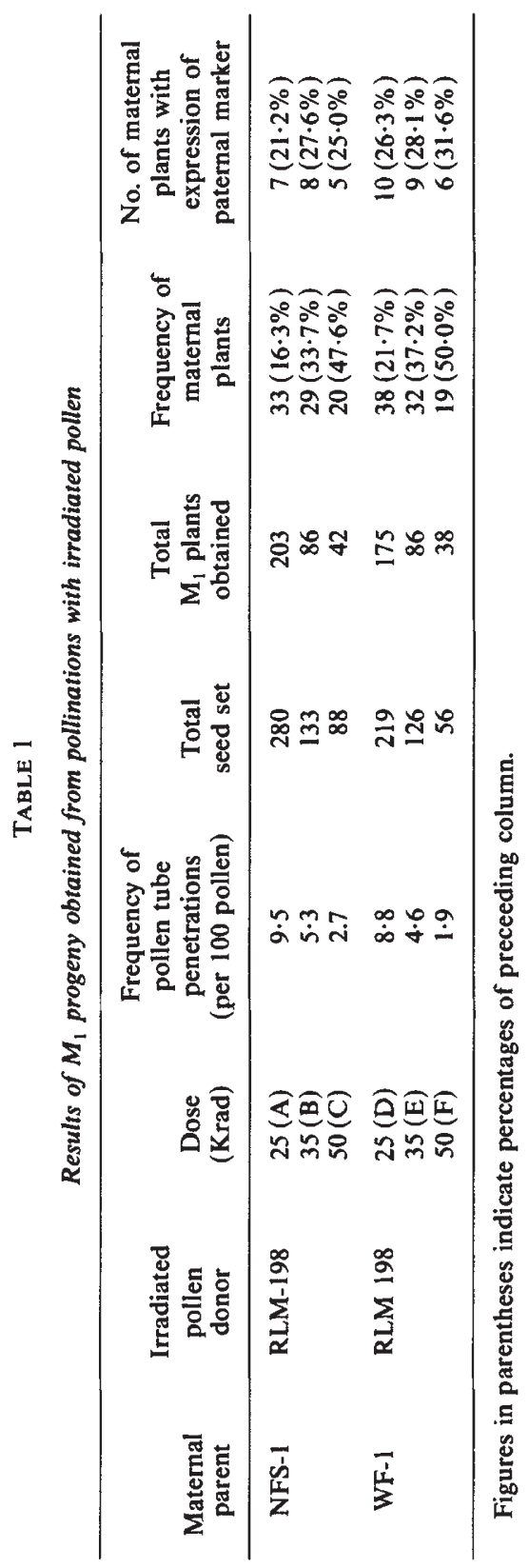


major gene markers (on all 300 plants) and quantitative characters (on fifty random plants) was carried out in both selected and unselected $\mathbf{M}_{2}$ groups.

\section{Results AND Discussion}

The plants derived from irradiated crosses were designated $M_{1}$ and those from unirradiated crosses as $F_{1}$. The frequency of pollen tube penetration and the yield of viable cross seeds decreased with an increase in radiation dose (table 1). Controlled pollinations with unirradiated pollen produced a large number of viable $F_{1}$ seeds. Each $F_{1}$ population was uniform and exhibited the dominant character of the pollen parent. The $M_{1}$ progenies revealed a varied expression for resemblance to either of the parents. The expression of the dominant paternal marker gene in a largely maternal phenotype was attributed to the gene transfer. The percentage of maternal plants in different $M_{1}$ progenies varied from 16.3 to 50.0 per cent whereas that of maternals with the expression of any paternal marker gene was $21 \cdot 2$ to 31.6 per cent. Spontaneous parthenogenesis was ruled out, as controlled emasculations without subsequent pollination failed to set seed.

TABLE 2

Segregation for major gene markers in selected and unselected $M_{2}$ families

\begin{tabular}{|c|c|c|c|c|c|}
\hline \multirow[b]{2}{*}{ Population } & \multirow{2}{*}{$\begin{array}{c}\text { Number of plants } \\
\text { scored in selected/ } \\
\text { unselected }\end{array}$} & \multicolumn{4}{|c|}{ Segregation for major genes in } \\
\hline & & Selected & $\chi^{2}$ & Unselected & $x^{2}$ \\
\hline \multicolumn{6}{|c|}{ False Vs no false septum } \\
\hline NFS-1 & 20 & $0: 20$ & & $0: 20$ & \\
\hline RLM-198 & 20 & $20: 0$ & & $20: 0$ & \\
\hline$F_{1}$ & 20 & $20: 0$ & & $20: 0$ & \\
\hline$F_{2}$ & 100 & $\begin{array}{l}79: 21 \\
(3: 1)\end{array}$ & 0.85 & $\begin{array}{l}77: 23 \\
(3: 1)\end{array}$ & 0.21 \\
\hline A & 300 & $246: 54$ & $7 \cdot 84$ & $16: 284$ & $776 \cdot 55$ \\
\hline B & 300 & $258: 42$ & $19 \cdot 36$ & $21: 279$ & 739.84 \\
\hline $\mathrm{C}$ & 300 & $261: 39$ & $23 \cdot 04$ & $23: 277$ & $725 \cdot 40$ \\
\hline \multicolumn{6}{|c|}{ Yellow Vs white flower } \\
\hline WF-1 & 20 & $0: 20$ & & $0: 20$ & \\
\hline RLM-198 & 20 & $20: 0$ & & $20: 1$ & \\
\hline $\mathrm{F}_{1}$ & 20 & $20: 0$ & & $20: 0$ & \\
\hline$F_{2}$ & 100 & $\begin{array}{l}73: 27 \\
(3: 1)\end{array}$ & $0 \cdot 21$ & $\begin{array}{l}76: 24 \\
(3: 1)\end{array}$ & 0.055 \\
\hline D & 300 & $241: 59$ & $4 \cdot 55$ & $26: 274$ & $704 \cdot 02$ \\
\hline $\mathrm{E}$ & 300 & $249: 51$ & $10 \cdot 24$ & $32: 268$ & $662 \cdot 20$ \\
\hline$F$ & 300 & $257: 43$ & $18 \cdot 20$ & $39: 261$ & $615 \cdot 04$ \\
\hline
\end{tabular}

Chisquare values were calculated with a null hypothesis of monogenic recessive inheritance.

The segregation ratios for the two marker genes are presented in table 2. The $F_{2}$ data supported the hypothesis of monogenic recessive inheritance $(3: 1)$. In the absence of the effects of pollen irradiation the progeny plants of each $M_{1}$ group were expected to segregate in a 3:1 ratio. However, all the $\mathrm{M}_{2}$ progenies deviated significantly from the theoretical expectations. The proportion of $\mathrm{M}_{2}$ plants having the dominant marker gene phenotype was very high in progenies which were derived from selected $M_{1}$ plants whereas it was very low in the progenies of unselected $M_{1}$ plants. The 
deviation of the $\mathrm{M}_{2}$ segregation in favour of the dominant class in the selected group is explainable if some of the selected plants were homozygous and others heterozygous for the transferred gene. Pandey (1980) has in fact shown the presence of both homozygous and heterozygous $M_{1}$ transformants. The occurrence of plants with paternal markers in $\mathbf{M}_{2}$ progenies derived from $\mathbf{M}_{1}$ plants without any evidence of transferred markers merits further investigation.

The analysis of the three quantitative traits revealed that means over all the selected $\mathbf{M}_{2}$ families differed significantly from $\mathrm{F}_{2}$ means except for secondary branches (table 3). On the other hand, unselected $\mathbf{M}_{2}$ families

TABLE 3

Analysis of some quantitative traits in $M_{2}$ generation of selected and unselected groups

\begin{tabular}{|c|c|c|c|c|c|c|}
\hline \multirow[b]{2}{*}{ Combination } & \multicolumn{2}{|c|}{ Days to bloom } & \multicolumn{2}{|c|}{ Plant height } & \multicolumn{2}{|c|}{ Secondary branches } \\
\hline & Selected & Unselected & Selected & Unselected & Selected & Unselected \\
\hline NFS-1 & \multicolumn{2}{|c|}{$52 \cdot 5 \pm 1 \cdot 02$} & \multicolumn{2}{|c|}{$73 \cdot 8 \pm 1 \cdot 03$} & \multicolumn{2}{|c|}{$31 \cdot 8 \pm 0.83$} \\
\hline RLM-198 & \multicolumn{2}{|c|}{$87 \cdot 5 \pm 1 \cdot 18$} & \multicolumn{2}{|c|}{$151 \cdot 6 \pm 1 \cdot 03$} & \multicolumn{2}{|c|}{$19 \cdot 5 \pm 0.76$} \\
\hline$F_{1}$ & \multicolumn{2}{|c|}{$96 \cdot 2 \pm 1 \cdot 15$} & \multicolumn{2}{|c|}{$162 \cdot 4 \pm 1 \cdot 02$} & \multicolumn{2}{|c|}{$38 \cdot 2 \pm 1 \cdot 39$} \\
\hline $\mathrm{F}_{2}$ & \multicolumn{2}{|c|}{$78 \cdot 4 \pm 3 \cdot 06$} & \multicolumn{2}{|c|}{$119 \cdot 9 \pm 3 \cdot 93$} & \multicolumn{2}{|c|}{$25 \cdot 6 \pm 2 \cdot 05$} \\
\hline$A$ & $70 \cdot 3 \pm 2 \cdot 05$ & $78 \cdot 6 \pm 2 \cdot 36$ & $106 \cdot 5 \pm 1 \cdot 95$ & $123 \cdot 2 \pm 1 \cdot 32$ & $28.9 \pm 2.03$ & $24 \cdot 2 \pm 1 \cdot 87$ \\
\hline B & $69 \cdot 5 \pm 2 \cdot 41$ & $75 \cdot 4 \pm 3 \cdot 10$ & $103 \cdot 2 \pm 2 \cdot 63$ & $119 \cdot 5 \pm 2 \cdot 13$ & $28 \cdot 4 \pm 2.46$ & $27 \cdot 3 \pm 1 \cdot 06$ \\
\hline C & $63 \cdot 2 \pm 3 \cdot 39$ & $69 \cdot 6 \pm 4 \cdot 75$ & $97 \cdot 4 \pm 4 \cdot 85$ & $107 \cdot 9 \pm 4 \cdot 56$ & $29 \cdot 2 \pm 4 \cdot 53$ & $28 \cdot 4 \pm 3 \cdot 85$ \\
\hline "t" between groups & \multicolumn{2}{|c|}{$2.67^{* *}$} & \multicolumn{2}{|c|}{$5 \cdot 56^{* *}$} & \multicolumn{2}{|c|}{0.93} \\
\hline " $t$ " $F_{2}$ vs. group & $3 \cdot 13^{* *}$ & 1.05 & $3.99^{* *}$ & 0.71 & $1 \cdot 17$ & 0.41 \\
\hline WF-1 & \multicolumn{2}{|c|}{$73 \cdot 5 \pm 1 \cdot 26$} & \multicolumn{2}{|c|}{$125 \cdot 3 \pm 0 \cdot 87$} & \multicolumn{2}{|c|}{$12 \cdot 4 \pm 0.76$} \\
\hline RLM-198 & \multicolumn{2}{|c|}{$86 \cdot 3 \pm 1 \cdot 38$} & \multicolumn{2}{|c|}{$149 \cdot 5 \pm 1 \cdot 02$} & \multicolumn{2}{|c|}{$19 \cdot 9 \pm 0.82$} \\
\hline$F_{1}$ & \multicolumn{2}{|c|}{$87 \cdot 4 \pm 0.59$} & \multicolumn{2}{|c|}{$161 \cdot 7 \pm 1 \cdot 74$} & \multicolumn{2}{|c|}{$19 \cdot 7 \pm 1 \cdot 95$} \\
\hline $\mathrm{F}_{2}$ & \multicolumn{2}{|c|}{$83 \cdot 5 \pm 2 \cdot 14$} & \multicolumn{2}{|c|}{$153 \cdot 6 \pm 2 \cdot 56$} & \multicolumn{2}{|c|}{$13 \cdot 8 \pm 2 \cdot 54$} \\
\hline D & $75 \cdot 6 \pm 2 \cdot 85$ & $80 \cdot 5 \pm 1 \cdot 35$ & $139 \cdot 8 \pm 2 \cdot 36$ & $141 \cdot 2 \pm 1 \cdot 36$ & $16 \cdot 3 \pm 1 \cdot 85$ & $16 \cdot 9 \pm 2 \cdot 68$ \\
\hline $\mathrm{E}$ & $72 \cdot 4 \pm 2 \cdot 38$ & $78 \cdot 9 \pm 1 \cdot 96$ & $134 \cdot 5 \pm 2 \cdot 76$ & $138 \cdot 3 \pm 2 \cdot 45$ & $14 \cdot 8 \pm 2 \cdot 06$ & $15 \cdot 7 \pm 3 \cdot 39$ \\
\hline$F$ & $68 \cdot 2 \pm 2 \cdot 79$ & $76 \cdot 5 \pm 2 \cdot 65$ & $132 \cdot 6 \pm 3 \cdot 88$ & $135 \cdot 2 \pm 3 \cdot 05$ & $13 \cdot 5 \pm 3 \cdot 47$ & $15 \cdot 6 \pm 3 \cdot 91$ \\
\hline "t" between groups & \multicolumn{2}{|l|}{$3 \cdot 36^{* * *}$} & \multicolumn{2}{|c|}{$1 \cdot 31$} & \multicolumn{2}{|c|}{0.49} \\
\hline "t" $F_{2}$ bs. group & $4 \cdot 33^{* *}$ & 1.99 & $5 \cdot 77^{* *}$ & $5 \cdot 17^{* *}$ & $0 \cdot 36$ & 0.71 \\
\hline
\end{tabular}

** Significant at $P=0 \cdot 01$.

with the exception of plant height in the cross WF-1 $1 \times$ RLM-198 did not differ from the $F_{2}$ means. Though both selected and unselected families deviated towards their maternal parent, they were significantly different from it $\left(t^{* *}\right)$. Increased radiation dosage led to greater resemblance to the maternal parent. In addition, all the $\mathbf{M}_{2}$ families revealed heterogeneity for the characters studied. Such situations are unexpected if pollen irradiation had no effect. These results can be explained by assuming the transfer, integration and expression of the random parts of the paternal genome into $\mathbf{M}_{1}$ and $\mathbf{M}_{2}$ progenies. The differences in the selected and unselected $\mathbf{M}_{2}$ families might be due to the influence of paternal parent to varying degree. It is evident (table 3 ) that the selected group had a comparatively greater influence of the maternal genome, and a deficit of paternal homozygotes, while in the unselected group there was a greater expression of paternal phenotype. Due to this very reason the unselected $M_{2}$ progenies behaved more like $F_{2}$. The differences between $F_{2}$ and $M_{2}$ though not significant were apparent in unselected families also. 
Our results are similar to those reported in Nicotiana and Barley. Thus the physiological and molecular processes involved in gene transfer may be similar. The interest of a plant breeder in these findings lies mainly in the possibility of effecting specific genome modifications in a quicker and more economical manner, and as a rapid technique for breaking linkages.

Acknowledgements. We are grateful to our anonymous reviewers for numerous suggestions which resulted in significant improvements in the presentation of our results. One of us (SSB) expresses his appreciation to the Department of Atomic Energy, Government of India, for the award of a Research Fellowship during his Ph.D. programme.

\section{REFERENCES}

BANGA, S. S. AND LABANA, K. S. 1983. Incidence of parthenogenetic maternals after prickle pollination of Brassica juncea (L.) Coss. Z. Pflzucht (In press).

CALIGARI, P. D. S., INGRAM, N. R. AND JINKS, J. L. 1981. Gene transfer in Nicotiana rustica by means of irradiated pollen. I. Unselected progenies. Heredity, 47, 17-26.

JINKS, J. L., CALIGARI, P. D. S. AND INGRAM, N. R. 1981. Gene transfer in Nicotiana rustica by means of irradiated pollen followed by selection. Nature, 291, 586-588.

PANDEY, K. K. 1978. Gametic gene transfer in Nicotiana by means of irradiated pollen. Genetica, 49, 56-69.

PANDEY, K. K. 1980. Further evidence for egg transformation in Nicotiana. Heredity, 45, 15-29. POWELL, W., CALIGARI, P. D. S. AND HAYTER, A. M. 1983. The use of pollen irradiation in barley breeding. Theor. Appl. Genet., 65, 73-76.

VIRK, D. S., DHAHI, S. J. AND BRUMPTON, R. J. 1977. Matromorphy in Nicotiana rustica Heredity, 39, 287-295. 